\title{
Mercury Policy and Regulations for Coal-Fired Power Plants
}

Manuela Rallo ${ }^{1}$, M. Antonia Lopez-Anton ${ }^{2} *$, M. Luisa Contreras ${ }^{3}$ and M. Mercedes Maroto-Valer ${ }^{1}$

${ }^{1}$ Energy and Sustainability Research Division, Faculty of Engineering, University Park, University of Nottingham, Nottingham, NG7 2RD, United Kingdom

${ }^{2}$ Instituto Nacional del Carbón (CSIC). C/ Francisco Pintado Fe No 26, 33011, Oviedo, Spain

${ }^{3}$ Unidad de Valorización Energética de Combustibles y Residuos. Dpto. Energía, CIEMAT, Avenida Complutense 22, 28040 Madrid, Spain

*Corresponding author

Phone: +34985119090

Fax: +34 985297662

e-mail: marian@incar.csic.es (present address)

malanton@hotmail.com (permanent address) 


\begin{abstract}
Mercury is a high-priority regulatory concern because of its persistence and bioaccumulation in the environment and evidence of its having serious adverse effects on the neurological development of children. Mercury is released into the atmosphere from both natural and anthropogenic sources. Coal-fired utilities are considered to be one of the largest anthropogenic mercury emission sources. The period since the late 1990s has been marked by increasing concern over mercury emissions from combustion systems to the extent that a number of national governments have either already implemented, or are in the process of implementing, legislation aimed at enforcing tighter control over mercury emissions and a reduction in mercury consumption. This review examines the most important national and international policies and agreements for controlling mercury emissions from coal-fired combustion systems. To provide a global perspective, this study lists the countries with the largest estimated mercury emissions and regulatory efforts to reduce them.
\end{abstract}

Keywords: mercury, pollution, legislation, control, emissions, coal combustion 


\section{Introduction}

In recent years, many countries have made efforts to reduce the emissions of harmful pollutants, including certain trace elements, of which mercury is considered the most important due to its high toxicity, persistence, and long lifespan in the atmosphere. Depending on the form and concentration of mercury, the routes of exposure, the levels of exposure and the toxicokinetic mechanisms, the occurrence of mercury can be very dangerous and have severe health effects in both aquatic and terrestrial ecosystems. Mercury organic and elemental mercury are considered to be of the greatest concern from the toxicological point of view (UNEP 2002). Methylmercury can be absorbed and can accumulate to a greater extent than other forms, building up in ecosystems and at the top of the food chain. These mercury compounds have the capacity to penetrate through cell membranes and react with essential proteins, amino acids and nucleic acids within the cells (WHO 1990). Some studies suggest that organic mercury exposure may cause neurologic and mental disorders as well as effects on the cardiovascular system (EC 2001a; Clarkson et al. 2003). Elemental mercury easily penetrates biological membranes, including the blood-brain barrier and accumulates in certain organs, such as the kidneys (WHO 2003). The International Programme on Chemical Safety (IPCS) concluded that, in long-term occupational exposure, levels of mercury vapor of c.a 20 $\mu \mathrm{g} \mathrm{m}^{-3}$ can have effects on the central nervous system (GreenFacts 2004).

As mercury is emitted to the atmosphere, it is cycled in both terrestrial and aquatic environments, transported and diluted before being deposited locally (Ebinghaus et al. 2009; UNEP 2008a; EC 2001b). The high concentrations of mercury found in both the Arctic and Antarctic far from the original sources of mercury emission areas that are virtually unpopulated, provides direct evidence of its long-range transport in air and justifies its classification as a global pollutant. 
Throughout the centuries, human activities, such as coal combustion, waste incineration, base metal smelting and the chlor-alkali industry, have greatly contributed to the higher mercury concentration in the air, water and soil sediments (CHM 2004; Holmes et al. 2009, Lindberg et al. 2007, Pirrone et al. 2003). However, while emissions from sectors, such as medical and municipal-waste combustion and the chloralkali industry (EC 2008a; UNEP 2011) are being reduced, emissions from coal combustion remain either constant or are not being reduced at the same rate (Fig. 1). This makes coal and oil burning in electric utilities as well as residential, commercial and industrial facilities the major sources of mercury emissions around the world. Mercury emissions from burning fossil fuels account for about $45 \%$ of the total amount of mercury emissions (1930 metric tonnes in 2005). The second major source of mercury release is associated with commercial products and industrial processes such as artisanal/small-scale gold mining (Pacyna EG et al. 2010). A significant contribution to mercury emissions also comes from metal and cement production and the chlor-alkali industry.

Fig. 1 Mercury emissions estimate from different sources during 1990 and 1999 (Data extracted from USEPA 2006)

Coal's contribution to mercury emissions varies worldwide depending on the different technologies employed in industrial processes, the degree of reliance on fossil fuels for energy and also the implementation of pollution control equipment in coal combustion systems for the generation of electricity (Fig. 2). In addition, the considerable uncertainty due to the limited number of direct measurements of emissions in some countries or to the application of various assumptions (such as the population distribution, economic activity) because of the lack of measurement, play a crucial role 
in national and/or global inventories. Despite the uncertainties involved at the global scale, Asian countries, such as China and India, where new coal-fired power plants are being built to meet the soaring energy demand, are the highest contributors to mercury emissions, followed by Europe, North America and Russia (Fig. 2) (Pirrone et al. 2010). $44 \%$ and $52 \%$ of mercury emissions are due to coal combustion in China and India, respectively (Pirrone et al. 2010; Wang et al. 2010a; Wu et al. 2006, 2010) whereas in Europe, North America and Russia the combustion of fossil fuels (primarily coal) represents 53, 43 and 66\%, respectively (Canada 2008; UNEP 2008b; USEPA 2005a). In other countries, such as Australia and South America, in addition to coal combustion, most mercury emissions seem to come from non-ferrous metal production and gold production, respectively (Nelson 2007; UNEP 2008b). According to the last estimates, coal-fired plants are also the largest contributors to mercury emissions in Canada and South Africa (Canada 2010; Masekoameng et al. 2010).

Fig. 2 Percentage of mercury emissions from stationary combustion in different regions. (Data extracted from Pirrone et al. 2010).

The period since the late 1990s has been especially marked by the increasing concern over mercury emissions and considerable efforts have been made to estimate anthropogenic mercury sources on a global scale as well as on a national scale (Masekoameng et al. 2010; Mukherjee et al. 2009; Nguyen et al. 2011; Pacyna EG et al. 2006a, 2006b, 2010; Pacyna JM et al. 2009; Pirrone et al. 2010, Tian et al. 2010; Wu et al. 2010). Several measures have also been taken by many countries to reduce these emissions in some strategic sectors. These include the 1998 New England Governors and Eastern Canadian Premiers (NEG/ECP) (NEG/ECP 1998), the North American 
Regional Action Plan (NARAP) (NARAP 2000), Norwegian Action Plan (NAP 2010) and many more that we will be reviewing in this paper. They all have the common goal of reducing man-made mercury emissions including the reduction of mercury pollution from combustion systems. However, the variation in mercury behavior in different power plants makes it difficult to generalize in terms of the applicability, effectiveness and costs of mercury-specific technologies, as several key factors affect mercury emissions and its consequential capture. For the most part, sorbent technologies, scrubbing technologies and boiler treatment additives, coal pre-treatment/cleaning strategies, coal and sorbent additives, and fuel blending are the generally accepted and nowadays commercialized technologies (Pavlish et al. 2010). Nevertheless, any progress made in this specific scientific field needs to be properly implemented through regulatory, market-based or voluntary programs. In addition, as more advanced power generation systems to limit $\mathrm{CO}_{2}$ emissions come under development, new emissions regulations will have to be introduced and mercury policy may attract increasing attention.

This study aims to provide an overview of the main international policies to regulate mercury and to show how different countries are aiming to reduce emissions and measures being taken both individually and globally.

\section{Mercury pollution: International agreements and cooperation}

Since the 1970s a considerable number of international policies, mainly research projects and cooperation agreements have been established in different countries. These policies were aiming to address environmental and human health risks from mercury exposure with the aim to co-ordinate international actions to reduce mercury emissions (Mercury Policy 2009; Selin and Selin 2006). Examples of these actions include the 
Organization for Economic Cooperation and Development (OECD) in 1973, which specifically urged its members to reduce the anthropogenic release of mercury to the environment to the lowest possible levels (OECD 1973); the 1972 International Convention on the Prevention of Marine Pollution by Dumping of Wastes and other Matter, (commonly called "The London Convention") which prohibited the dumping of mercury at sea (Convention 1972a). Several European agreements have also been concluded to limit or reduce mercury emissions, such as the Oslo and Paris Conventions (Convention 1972b, 1974a). The Oslo Convention prohibited the dumping of mercury, while the Paris Convention obligated all parties to eliminate mercury pollution of maritime areas from land-based sources. The Helsinki Commission (HELCOM) strictly limited emissions of mercury into the Baltic Sea (Convention 1974b), while, The Barcelona Convention, a programme similar to HELCOM, established a series of similar protocols covering the Mediterranean Sea (Convention 1976; Protocol 1976, 1980). Canada and the United States (U.S.) signed the Great Lakes Water Quality Agreement in 1972 (GLWQA 1972). This agreement was updated in 1978 (GLWQA 1978) when Canada and the U.S. pledged "to restore and maintain the chemical, physical and biological integrity of the waters of the Great Lakes Basin Ecosystem”. Regarding mercury, maximum concentration limits were agreed upon "to protect aquatic life and fish-consuming birds". We can also add to this list of binding agreements, the 1973 MARPOL Convention and the 1978 Protocol for the prevention of pollution from ships which define guidelines to eliminate releases of mercury into the environment from mercury containing waste (MARPOL 1973/1978).

During the last two decades several governments and cooperative organizations were working on the introduction of guidelines or legislation to limit or reduce mercury emissions. For example, in 1988, the HELCOM Ministerial Declaration stated their 
intention to reduce the total discharge of mercury and adopted a series of binding recommendations targeting specific mercury uses and sources of emission (HELCOM 1988). Other directives even estimated the mercury reductions needed to achieve. For example, the North Sea Directive, enacted in 1990, proposed a $70 \%$ reduction in the total input of mercury to the North Sea from human activities by 1999, the 1985 emission levels serving as the baseline. The countries included in this agreement were Belgium, Denmark, France, Germany, the Netherlands, Norway, Sweden, Switzerland and the United Kingdom (Wiederkehr 1993). The OSPAR Convention (Convention for the Protection of the Marine Environment of the Nort-East Atlantic) combined and updated the Oslo and Paris Conventions (Convention 1992) entering into force in 1998. Similarly to HELCOM, the OSPAR Commission (OSPAR 2009) has adopted a number of Decisions and Recommendations concerning mercury. They were related mainly to the reduction of discharges of mercury from chlor-alkali industry. Mercury outlet, especially from chlor-alkali plants has been on the agenda since 1980 where PARCOM made decisions to limit the outlet from this industry. In PARCOM decision 90/3 (PARCOM 1990), it was proposed the reduction of chlor-alkali mercury emissions to 2 grams of mercury per tonne of $\mathrm{Cl}_{2}$ capacity and that the use of the mercury technology in chlor-alkali production should be completely phased out in the OSPAR countries by 2010 (PARCOM 1990). However, in the light of insufficient progress of this objective, the European Parliament called on the European Commission to take action to implement the OSPAR Decision. Meanwhile, industry has recently offered a voluntary agreement that sets a date for closure or conversion at 2020, without legal obligation if this agreement is not met.

From a more global perspective, the Basel Convention on the Control of Transboundary Movements of Hazardous Wastes and their Disposal in 1989 identified 
mercury as one of the priority pollutants (Basel 1989). The Basel Convention sought to protect human health and the environment by minimizing the generation of hazardous wastes and controlling and reducing their transboundary movement (Kummer 1995) through an integrated life-cycle approach. In fact, the Convention based to strong controls from the generation of a hazardous waste to its storage, transport, treatment, reuse, recycling, recovery and final disposal. At the present, 178 countries have ratified the Convention. Mercury and mercury compounds are covered under the technical scope of this Convention, including also fly-ashes from coal-fired power plant. The Basel Convention currently regulates some of the aspects of mercury management identified by the international community for priority action. The Convention maintains its position as very relevant and modern global instrument to address mercury-related issues and usefully contributes to the undertaking of global measures on mercury, either through legally-binding frameworks or voluntary work. Thus, it should be considered as a key contributor to any international action to address mercury issues in the future.

Other relevant international convention is the Convention on Long-Range Transboundary Air Pollutants (CLRTAP) under the direction of the United Nations Economics Commission for Europe (UNECE). This Convention entered into force in 1983 and now has 51 Parties, including Europe, Russia, Canada and U.S. The aim of the Convention is that all Parties should endeavour to limit and gradually reduce and prevent air pollution, including long-range transboundary air pollution, through a number of co-operative programmes. This Convention has been extended by the addition of eight protocols that specify the measures to be taken by the Parties to cut their emissions of air pollutants (UNECE 2000). Each protocol addresses a specific pollutant or groups of pollutants. In particular, the Protocol on Heavy Metals (Protocol 1998) which came into force in December 2003 and has now 30 Parties, targets three 
particular metals harmful to human health and the environment: mercury, lead and cadmium. The Protocol, which represents the largest and concrete international treaty on mercury, aims to cut emissions from stationary industrial sources, combustion processes and waste incineration. The Protocol also suggests the use of the Best Available Techniques (BAT), such as special filters, scrubbers or mercury-free processes in order to achieve these targets, although it does not specify any reduction strategy (Sloss 2008). Regarding stationary combustion sources, combustion installations with a net rated thermal input exceeding 50MW are also included (Gibb et al. 2003; Protocol 1998; Sloss 2008; UNECE 2000). Between 2009 and 2010, the Executive Body of the CLRTAP Convention decided to revise the Protocol, by starting and broadening negotiations, in order to include aspects of mercury-containing products with the aim of facilitating for non-parties to accede to an amended Protocol in 2012 at the latest (Brussels 2011). More precisely, the revision aims mainly at regulating the export and the disposal of mercury, and introducing specific requirements concerning mercury. This revision of the Protocol is of considerable importance. In fact, its revision by producing a guidance document, updated as appropriate, will possibly make the Protocol more adaptable to future developments.

Parallel to the assessment work on heavy metals carried out under CLRTAP, the eight Arctic countries (all of which are also CLRTAP parties) surveyed issues of longrange atmospheric transport and heavy metals pollution in the Arctic environment. The subsequent report published by the Arctic Monitoring and Assessment Programme (AMAP) in 1997 noted that mercury levels in the Arctic environment were increasing. The report and subsequent updates suggested that the Arctic countries should explore the possibility of developing an additional international mechanism to address the 
transboundary transport of heavy metals emissions which cause the contamination of aquatic or terrestrial environments (AMAP 1997-1998, 2002, 2010, 2011).

More recently, scientists and politicians have intensified efforts to reduce global mercury pollution. In 2002, the Governing Council (GC) of the United Nations Environment Programme (UNEP) initiated a global assessment of mercury and its compounds in cooperation with other members of the Inter-Organization Programme for the Sound Management of Chemicals (IOMC) (UNEP 2002). The effort of the Arctic countries to curtail the risk of mercury pollution also continued in this period. In fact, mercury has been on the UNEP GC's agenda since 2001 and with the Global Mercury Assessment of December 2002 it was acknowledged by participating countries that mercury was a serious global problem. More specifically, the report summarises information about the sources, long-range transport, chemical transformation and fate of mercury. Moreover, it includes discussion about control technologies with their associated costs and about the effects and impact of mercury on human beings and their ecosystems. As a result of this report, the UNEP Governing Council drew up a comprehensive Mercury Programme. This is an important step in setting and implementing national, regional and global priorities, as well as, establishing baselines to monitor and assess progress on mercury reductions.

Before the UNEP Governing Council session in 2005, 25 governments submitted written views on further action to be taken. Several countries, including Guinea, Moldova, the Philippines, Sweden and Switzerland, supported negotiating a legally binding agreement on mercury and/or heavy metals, while Australia, Canada and the U.S. continued to emphasize voluntary measures (UNEP/GC 2004). During the UNEP GC meeting in 2005, discussions focused on the pros and cons of a legally based approach favoured by the European Union (E.U.) and several developing countries 
versus a voluntary partnership approach supported mainly by the U.S. Australia, Japan and Canada, but the main conclusion was that mercury is a significant international problem that warrants political action.

At its twenty-fifth session, in 2009 , the GC came to a decision about a number of matters that will influence the global response to mercury emissions in the future. In particular, the GC decided to prepare a global legally binding instrument (LBI) on mercury to be completed prior to the twenty-seventh regular session of the GC, which is scheduled to take place in 2013 (UNEP 2008a, 2008b, 2009). In view of the third session of the Intergovernmental Negotiating Committee (INC3) in November 2011, Governments submitted a draft of their visions regarding a comprehensive and suitable approach to a legally binding instrument on mercury, as well as information on releases of mercury from the oil and gas sector and information on the use of mercury as a medical preservative.

\section{Policies of mercury control from coal-fired power plants.}

As previously mentioned, fossil fuel-fired power plants are the largest sources of mercury released into the atmosphere. It is essential to control these emissions at all levels-global, regional and local-in order to achieve reductions in global anthropogenic emissions. Although many countries have already introduced regulatory or legislative action programmes, reduction targets and ambient air-quality standards for mercury (Davison et al. 2003), few have established enforceable emission standards for coalfired power stations.

Mercury emissions from stationary combustion facilities depend on the type and efficiency of the control equipment, such as electrostatic precipitators (ESPs) and fabric filters (FFs) that are now commonly used as a means of abatement in major electric 
power plants and central heating plants all over the world. Flue gas desulfurization (FGD) units are also used to control emissions but they are not common, especially in developing countries. These flue gas cleaning technologies are able to reduce mercury emissions as a co-benefit of controlling other pollutants (USEPA 1997a, 2002a, 2002b; Wang et al. 2010a). A comparison of world-wide mercury emissions (Pirrone et al. 2010) suggests that Europe and North America are reducing their contribution to the global mercury burden, while emissions in Asia are increasing, the latter driven primarily by the upward trend of the energy demand which in the last decade has grown at a rate of 6 to $10 \%$ per year. A detailed analysis carried out within the UNEP report on Global Atmospheric Mercury Assessment indicates that the increase in Asian emissions is primarily due to the rise in mercury emissions in China followed by India (UNEP 2008a).

The following sections examine the policy developments and plans of action designed to reduce the emissions of mercury from coal combustion processes in those countries with the greatest contributions to global mercury emissions (Asia, U.S. and Europe), either through mercury-specific legislation or as a co-benefit from legislation intended for other pollutants. Canada will also be included in the study because, although its contribution to global mercury emissions is not as high, coal-fired power plants continue to be the largest single remaining anthropogenic source of mercury emissions in this country and it has established specific mercury limits for this sector.

\subsection{Policy and outlook for Asia}

Mercury is a growing problem particularly in Asia where countries often lack the domestic capacity to address mercury pollution and contamination. China with more than 200 coal-fired power plants, is the largest single emitter of mercury to the 
atmosphere ( 33\%) (Fig. 2) (Pirrone et at. 2010). Coal combustion has therefore resulted in elevated mercury concentrations in the air of some cities (e.g. Beijing, Guiyang, Chongqing) (Fang et al. 2004; Feng et al. 2003; Liu et al. 2002). Reducing mercury pollution has been a high priority within China's environmental management and improvement program. During the past few years, China's State Environmental Protection Administration has also tightened its control over the production, use, import, export, and disposal of mercury (Jiang et al. 2006). For example, most-chloralkali production processes have been closed down or converted to mercury-free technologies. Mercury mining has also been restricted in many areas and artisanal goldmining activities have been banned since 1996 (Qi et al. 2000). However, without a feasible solution that includes a set of alternatives bans might be not the correct solution. On the other hand, converting to mercury-free alternatives requires reducing both demand and supply, simultaneously. In order to proper address the mercury strategy, demand reduction should be driven by an appropriate politic of the community, while supply should be reduced through suitable legislation that progressively restricts importation and availability.

China has still not set strict regulations for mercury emissions from coal combustion. Mercury emissions from China are particularly difficult to project due to current emission control policies and possible changes in these policies in the near future. The majority of China's power plants are owned and operated by Chinese companies. Under national regulations, many plants have the option of paying the government annual fees rather than installing emission control equipment. However, this is fast changing. The $\mathrm{SO}_{2}$ emission control policies adopted during recent years have had significant co-benefit for mercury reductions. The government imposed regulations in 1998 on the sulphur content of coal used in urban environments (Linqing 
1999) and clean coal technologies are increasingly being installed. By 2008 over $95 \%$ power plants installed ESPs and 71\% of them (460GW) installed FGD units in 2009 (China 2006-2009). In fact, mercury emissions fell by approximately 31 metric tonnes during 2005-2008 due to the installation of FGD units and the closure of small units (Wang 2011). If all Chinese power plants are equipped in 2020 with ESPs and FGDs that have the emission reduction efficiency of those installed in the U.S. and Western European power plants (i.e 30-90\%), emissions from Chinese power plants in 2020 will be at the same level as they are today (Pacyna JM et al. 2008). In the best probable scenario, the total mercury emissions from coal-fired power plants in China could decrease to approximately 120 metric tonnes by 2020 due to the rapid installation of fabric filters and selective catalytic reduction (Wang et al. 2010b). However, there is still a great deal of uncertainty associated with the current mercury emission inventory. Further studies on mercury emissions from coal combustion need to be carried out and strict regulations must be introduced.

While the population of China until 2020 is projected to grow at a slow rate $(\sim 0.47 \%)$, a much faster population growth is expected in other countries such as India which is also known for its high mercury emissions from coal-fired power plants. Mercury emissions, therefore, could increase in India much faster than in China.

There have been some initiatives by the Indian government to reduce industrial mercury emissions from mercury-cell chlorine plants by converting these plants to membrane technology, which is mercury-free (Mukherjee et al. 2009). However, it is unfortunate that the Indian government has not taken any decision regarding mercury emissions from coal combustion plants. Moreover, India has serious problems with municipal solid waste, hazardous waste and electronic waste. Although, the Indian Supreme Court banned the import of hazardous waste in 1997, it is still finding its way 
into the country (IEP 2011). Another problem is that the Indian brick industry produces 140 billion bricks and consumes $24 \mathrm{Mt}$ of coal from which an estimated 7 metric tonnes per year of uncontrolled mercury is emitted. There are 170 opencast mines, 359 underground and 33 mixed mines and approximately $70-80 \%$ of the heat and electricity production in India depends on the combustion of coal in approximately 85 coal-fired power plants (Mukherjee 2008; Mukherjee and Zevenhoven 2006). In short, the chief concern is that, despite its good intentions, the Indian government is still unable to check or control mercury pollution. Like China, India could reduce mercury emissions from coal combustion in the future as a co-benefit derived from the use of control technologies intended for other pollutants. In India, most stations are equipped with ESPs, barring a few that use bag filters. However, very few power plants are equipped with FGD units (UNEP 2008-2009).

Among the objectives under the UNEP Mercury programme for reducing mercury emissions from coal combustion is the optimization of multi-pollutant control technologies, including the improvement of energy efficiency, and the targeting of countries such as China, India, Russia and South Africa (UNEP 2010a). Currently the UNEP is working with different Governments to strengthen the UNEP Global Mercury Partnerships (UNEP 2009-2010). Several co-operation agreements have been signed under this programme. The Ministry of Environmental Protection and Tsinghua University in China are currently completing one of the largest ever projects to evaluate the mercury content of coals in China and to estimate current and future emissions from the coal utility sector. A similar updating of this type of information is being carried out in South Africa and Russia. These two countries are also expected in the future to increase the electricity supply from coal combustion in order to meet the ever-increasing energy demand. In 2007 Canada provided two trainees from China with training on how 
to measure mercury emitted from fossil fuel combustion. Through a Bilateral agreement between the U.S. and India, information and other assistance has been provided to India in order to increase the effectiveness of pollution controls at coal-fired power plants. For example, Indian personnel received specific training at a U.S. Environmental Protection Agency (EPA) on how to use software tools to help optimize ESP with co-benefits for reducing mercury emissions (UNEP 2008c). There is also a need for other countries to support countries like India in promoting actions that will reduce mercury emissions from coal combustion.

\subsection{Regulatory framework and legislation in the United States}

The U.S. has been the catalyst of a number of global mercury partnerships aimed at achieving substantial early reductions in the use and emissions of mercury throughout the world. This has led, among other measures, to mercury-specific legislation for coal combustion in certain states in the U.S.

Since the Clean Air Act (CAA) was amended in 1990, the USEPA (United States Environmental Protection Agency) has been given authority to control and regulate hazardous air pollutants (HAPs) from major sources of emissions to the air. Specifically, the CAA required the U.S. Environmental Protection Agency to identify HAP sources, quantify the emissions according to source category, develop regulations for each source category, and assess the public health and environmental impacts after regulations were implemented. The EPA presented a list of 189 hazardous air pollutants thought to be relevant to emissions from coal combustion and gasification plants and concluded that eleven of these hazardous air pollutants were trace elements, among which mercury and its compounds were the greatest concern (under section 112 of the 1990 Amendments to the Clean Air Act). 
With the publication of "Mercury Study Report to Congress" in December 1997 and of the "Utility Air Toxic Study" in February 1998, EPA identified coal-fired utility boilers as the largest sources of mercury in the U.S. (USEPA 1997b, 1998). In the late 1990s, the U.S. federal government began to regulate mercury emissions from municipal and medical waste incineration under the Clean Air Act. As a result, mercury emissions in the U.S. decreased by $45 \%$ between 1990 and 1999 whereas the relative contribution from coal-fired utilities increased. Coal-fired utilities now contribute about $43 \%$ of U.S. emissions of mercury (approximately 43 metric tonnes/year) (UNEP 2010b).

In December 2000, in a Federal Register bulletin, EPA stated that fish consumption is the primary pathway for human and wildlife exposure to mercury and that there is a plausible link between emissions of mercury from anthropogenic sources (including coal-fired utility units) and methylmercury in fish (USEPA 2000). EPA also stated that it was "appropriate and necessary" to regulate mercury from coal-fired utility boilers using Section 112 of the CAA. EPA has continued over the years on both the domestic and international front to reduce mercury release to air, water, and land, proposing more efficient and more cost-effective regulations and measures for controlling and reducing mercury emissions. In particular, EPA has focused on the development of Maximum Achievable Control Technology (MACT) standards for mercury emissions and for each categorized source.

In January 2004, EPA revised the December 2000 "appropriate and necessary”, finding that listing utility boilers under Section 112 was an error and suggested regulating them under the "new source performance standard provisions" of section 111. EPA also offered another alternative: regulating the power plants under section 112 
but without following that section's prescriptions regarding MACT standards (USEPA 2004a, 2004b).

Finally, in 2005, EPA issued a ruling to permanently cap and reduce mercury emissions from coal-fired power plants for the first time ever, the Clean Air Mercury Rule (CAMR). The CAMR established mechanisms and standards for limiting mercury emissions from new and existing coal-fired power plants. Under the George W. Bush administration a market-based cap-and-trade program was proposed to cap utility emissions of mercury in two phases with phase I aiming at a cap of 34 metric tonnes of mercury by the beginning in 2010 and phase II aiming at a final cap of 14 metric tonnes by 2018 (USEPA 2005b, 2005c). Currently, the estimate of mercury emitted from coalfired power plants is 43 metric tonnes. Therefore, the 2010 and 2018 reductions represent 21 and 69\%, respectively. With the implementation in March 2005 of the Clean Air Interstate Rule (CAIR) (USEPA 2005d) to reduce emissions of $\mathrm{SO}_{2}$ and $\mathrm{NOx}$ in the 28 eastern states, it was expected that the initial phase of CAMR would largely be met with the installation of wet scrubbers and selective catalytic reduction (SCR) systems. However, a cap of 15 tons as required by the second phase of CAMR would require additional mercury-specific controls, such as activated carbon or other sorbent injection systems, at many plants (USEPA 2005c). As CAMR was being developed and finalized, some states conducted their own rulemaking to implement the requirements. By December 2007, 23 states had proposed or adopted rules that were more stringent than CAMR, with 16 states prohibiting or restricting interstate trading of emissions allowances (NACAA 2007). Following a model rule developed by the National Association of Clean Air Agencies, several states adopted demands for emissions reductions of $80 \%$ or emissions limits of about $1 \mathrm{lb} / \mathrm{TBtu}$ in an initial phase, followed by a second phase requiring $90 \%$ reductions or emissions limits of about $0.6 \mathrm{lb} / \mathrm{TBtu}$ 
(Milford and Pienciak 2009). After CAMR, several states and organizations petitioned the Court of Appeals for a review.

After several hearings, on 8 February 2008, the District of Columbia Circuit (D.C. Circuit) vacated the CAMR (USEPA 2008a). The U.S. Department of Justice appealed against the decision before the U.S. Supreme Court.

EPA had been relying on the co-benefits of CAIR for most of CAMR's Phase I reductions. On July 11, 2008, the D.C. Circuit Court of Appeals vacated the CAIR, finding that the rule's cap-and-trade program for sulphur and nitrogen oxide emissions failed to satisfy the explicit CAA requirement that upwind states should prohibit emissions contributing significantly to the violation of air quality standards in downwind states (USEPA 2008b). However, in response to a petition for a rehearing, the court subsequently agreed to remand but not vacate the rule, so that the ruling will remain in force until EPA addresses its deficiencies. With CAIR reinstated, the mercury reductions expected as a co-benefit from the control of other pollutants should come into effect.

In January 2009, the U.S. Department of Justice, on behalf of the EPA, asked the United Stated Supreme Court to dismiss the appeal against the CAMR vacatur. In February 2009, EPA announced its intention to develop emissions standards for all HAPs including mercury under Section 112 of the CAA (USEPA 2009). Utilities were notified of an Information Collection Request (ICR) to collect data on HAP emissions (and controls) from coal- and oil-fired utility boilers in December 2009.

Finally, on 16 March 2011, EPA proposed the first national standard to reduce mercury and other toxic air pollution from coal and oil-fired power plants (USEPA 2011). This proposal sets technology-based emissions limitation standards for mercury and other toxic air pollutants, reflecting levels achieved by the best-performing sources 
currently in operation. With the EPA expected to issue a national regulation on November 16, 2011 requiring 91\% removal of mercury from the flue gas of existing coal-burning power plants, and many states promulgating their own regulations, the need exists for low-cost mercury removal techniques that can be applied to coal-burning power plants. The injection of powdered activated carbon into the ductwork upstream of the particulate control device is the most developed technology for mercury capture. Alternative techniques for mercury capture will also play a role in the near future because of the numerous configurations of air pollution control devices present within the power plants, as well as the many different coals being burned. These methods employ sorbents, catalysts, scrubber liquors, flue gas or coal additives, combustion modification, flue gas cooling, barrier discharges, and ultraviolet radiation for the removal of mercury from flue gas streams (Granite et al. 1999, 2000, 2007; Granite and Pennline 2002; Manivannan et al. 2005; Maroto-Valer et al. 2005; Presto and Granite 2008). The United States Department of Energy's Mercury Program has sponsored over 85 million dollars of research since the early 1990's, and has been a huge success, spurring development, demonstration, and commercialization of many technologies for the capture of mercury (Feeley et al. 2003, 2008, 2009). In the meantime, mercury emissions from existing sources are expected to decline due to independent rules adopted by many states and also to the co-benefit expected from controls installed and intended for other pollutants (Milford and Pienciak 2009).

\subsection{European Community initiatives and strategy}

Although mercury-specific legislation at large scale coal-fired power plants has still not been established in Europe, specific scenario projections show that mercury 
emissions from power plants in Europe could be reduced by as much as $60 \%$ by 2020 (Glodek and Pacyna JM 2009; Pacyna EG et al. 2010; Pacyna JM et al. 2009).

The European Commission (EC) has introduced measures to prevent or reduce mercury pollution caused by the incineration or co-incineration of waste through Directive 2000/76/EC (EC 2000). Although the Directive is not aimed specifically at coal-fired furnaces, it applies to them also, if the fuel classed as "wastes" is co-fired with coal, a common practice in countries such as the Netherlands (Meij and Winkel 2009). The Directive sets total mercury emission limit values in the discharge of waste water and in the gaseous/vapour phase (EC 2000).

The implementation of Directives such as 2008/1/EC on Integrated Pollution Prevention and Control (IPPC) in 2008 (EC 2008b) and 2001/80/EC on the limitation of emissions of certain pollutants into the air from Large Combustion Plants (LCP) in 2001 (EC 2001b) is contributing indirectly to the reduction of mercury emissions from coalfired plants in Europe. The IPPC directive also provides information on the annual emissions of large and medium-sized industrial plants in accordance with the Commission Decision in 2000 to establish the first European-wide register of industrial emissions into air and water, the European Pollutant Emission Register (EPER) (EPER 2000).

The IPPC Directive (EC 2008b) establishes a set of common rules for permitting, controlling and minimising emissions from new or existing agricultural and industrial sources (combustion installations included) with a high pollution potential. This directive is a permit based scheme which introduced the concept of Best Available Techniques (BAT). BAT, defined as the most effective and advanced stage in the development of activities, must be taken as fundamental for the emission limit values (ELVs) of polluting substances. The Directive does not contain specifics for mercury 
but covers the category metals and their compounds, with mercury being listed among the main polluting substances to be taken into account for reducing emissions to air, water and land.

The LCP Directive (EC 2001b) aims to reduce acidification, ground level ozone and particles throughout Europe by controlling emissions of sulphur dioxide $\left(\mathrm{SO}_{2}\right)$, nitrogen oxides $\left(\mathrm{NO}_{\mathrm{X}}\right)$ and dust particulate matter $(\mathrm{PM})$ from large combustion plants. The LCP Directive, like the IPPC Directive, applies to combustion plants with a thermal output greater than $50 \mathrm{MW}$, irrespective of the type of fuel used (solid, liquid or gaseous) and also sets emission limit values for both new and existing plants.

On 8 November 2010, the European Council approved the revised Industrial Emissions Directive (IED) (EC 2010). The IED is a recast of seven existing Directives, including the IPPC Directive (2008/1/EC of January 2008) and the LCP Directive (2001/80/EC) related to industrial emissions. European legislators felt that a recast was necessary to update and streamline existing legislation to bring it into line with technological and political developments and to minimise distortions resulting from competition within the European Union (E.U.). One of the main reasons for the recast of the IPPC Directive was the inadequate and incoherent implementation of BAT throughout the E.U. In addition, the IED extends the scope of the IPPC Directive to cover additional installations (eg, combustion plants between 20 and $50 \mathrm{MW}$ ). The Directive extends the lifespan of combustion plants, allowing installations that would have been forced to close in 2016 to continue generating until 31 December 2023 provided certain operational restrictions are complied with.

The directives mentioned above are indirectly contributing to the task of reducing mercury emissions. The E.U. has already made considerable progress in addressing the global challenges posed by mercury by having it listed for consideration 
in the assessment and management of ambient air quality, under the European Commission's Air Quality Framework Directive (Council Directive 96/62/EC). To better fulfil the requirement of Council Directive 96/62/EC and to support the preparation of "Daughter Directives" a Technical Report on mercury was prepared in 2001 by a group of experts. The so-called, "Position Paper on Mercury" is based on European sources and major processes/mechanisms that influence the mercury cycle and its impact on human health in Europe. Subsequently, mercury was incorporated into the Fourth Air Quality Daughter Directive, "Directive 2004/107/EC of the European Parliament and Council relating to arsenic, cadmium, mercury, nickel and polycyclic aromatic hydrocarbons (PAHs) in ambient air". Although the Directive does not contain any mandatory limit values for the mercury ambient air concentrations, it requires the establishment of methods and criteria for the assessment of mercury concentrations in ambient air and for its disposal (EC 2004).

In 2005 the European Commission launched the E.U.'s mercury strategy which explains the E.U. position concerning the international discussion on mercury. The E.U.'s mercury strategy is a comprehensive plan that addresses the problem of mercury pollution both inside the E.U. and globally. It contains 20 measures for reducing mercury emissions, reducing the supply and demand and protecting against exposure, especially to the methylmercury found in fish. In this strategy large coal combustion plants are identified as the largest emitters of mercury compounds into the atmosphere in Europe. In developing its mercury strategy the Commission has prepared an Extended Impact Assessment (ExIA). This looks at aspects ranging from the use of mercury in measuring and control equipment to the control of mercury emissions from large combustion plants (EC 2005). Since then, the European Union has also partially funded the Process Optimization Guidance (POG) document for reducing mercury 
emissions from coal combustion in power plants through the UNEP (UNEP 2010b). The POG document summarizes practices that contribute to the reduction of mercury emissions from coal-fired power plants. These practices include energy efficiency improvement measures, pre-combustion control/prevention measures (e.g., coal blending, coal cleaning), maximization of control of mercury emissions from plants already equipped with non-mercury emission control technologies, and multipollutant control processes that could be co-utilized to reduce mercury emissions (Sloss 2006, 2009). The document also reviews mercury-specific control processes and raises the matter of the cost of mercury emission control systems. Large economic benefits can be achieved by reducing global mercury emissions (Pacyna JM et al. 2010; Sundseth et al. 2010). On 14 March 2011, the Council issued its conclusions on the E.U.'s review of the Community Strategy concerning mercury, which recognizes, among other aspects, the potential of IED to achieve considerable emission reductions from large point sources (Council 2011).

\subsection{Canadian regulation}

The Canadian Council of Ministers of the Environment (CCME) has determined that the large levels of mercury in fish and wildlife across Canada warrant efforts to reduce mercury emissions in order to protect not only fish and wildlife, but also human health (CCME 2006a).

Since 1998, CCME has set Canada-wide Standards (CWSs) for mercury emissions from base-metal smelters and from waste incinerators, as well as CWSs for mercury-containing lamps and dental amalgam waste. Canada has also signed three international agreements that outline various mercury management programmes, including the North American Regional Plan on Mercury (with the United States and 
Mexico), the Great Lakes Binational Toxics Strategy (with the United States) and the UNECE Heavy Metals Protocol (International) (PP 2003) since Canada receives ten times more mercury from the global pool than it emits each year. In addition, the five eastern provinces of Canada signed the Eastern Canadian Premiers/New England Governors Mercury Action Plan. All of these agreements call for measures to reduce the use and/or emission of mercury.

In 2003, the coal-fired electric power generation sector emitted an estimated 2.7 metric tonnes of mercury of the 3.7 metric tonnes of the mercury estimated to be present in the coal burned. Therefore, the CCME has agreed to set mercury CWSs for this sector, with the goal of reducing mercury emissions from existing plants while ensuring that new plants achieve emission levels based on the best economically available technology and equipment (CCME 2006a).

The CWSs have set a cap on mercury emissions from each coal-fired electric power generation plant and for each province. As new units are installed, the cap cannot be exceeded. Thus, additional reductions are required from existing sources to accommodate the addition of new sources. Some of these reductions will come from the decommissioning of old units (CCME 2006a).

Many provinces in Canada have already taken action towards mercury reduction (Sloss, 2008). As an example, in Alberta, the Clean Air Strategic Alliance Electricity Project Team recommendations have been implemented (CCME 2006a). In 2003, the Saskatchewan coal-fired electric power generation sector emitted approximately 0.71 metric tonnes of mercury of the approximately 0.77 metric tonnes of mercury in the coal burned. Therefore, the CCME including Saskatchewan has agreed to set a mercury CWS for coal-fired power plants (CCME 2006b). The measures taken in Saskatchewan, between 2004 and 2009, will serve to meet its provincial caps for the years 2010 to 
2013. Ontario has set itself the goal of zero mercury emissions from coal-fired power generation, as coal-fired generation is gradually phased out (CCME 2006a, OCAA 2004).

\section{Conclusion}

There is abundant evidence that mercury and its compounds are highly toxic to humans, ecosystems and wildlife. Research and monitoring over the years have provided ample justification for the need to taking measures to reduce mercury emissions from coal-fired power plants which is the main source of such emissions in many countries. The E.U. has reduced mercury emissions due to measures taken to tackle emissions of other pollutants. Even without mercury-specific legislation for coal combustion plants, these reductions are expected to continue for the next decade due to the co-benefit effects from impending legislation. Mercury-specific legislation has been passed in Canada and certain states in the U.S. and mercury reductions are expected to continue in these countries. However, in other countries, such as China and India, an increase in mercury emissions from coal combustion is expected due to the high energy demand and the lack of legislation and control for mercury pollution. China is currently the largest emitter of mercury from coal-fired power plants. Although mercury emissions in China have been reduced from the co-benefits offered by sulphur control units, these measures may not be sufficient in the future due to continued growth. Unless emission control devices and regulations are implemented, not only in Asian countries but also in countries such as South Africa and Russia, the contribution of mercury emissions from coal combustion will continue to increase.

There is still the need to further address and coordinate measures and activities at the global level to ensure that future research provides the maximum benefits in terms 
of assessing trends in mercury emissions. In addition, local knowledge of the industrial sectors, economy and future plans for national legislation is also necessary in order to achieve a detailed assessment of alternative control technologies for reducing mercury emissions.

Although voluntary actions, such as partnerships, are reasonably significant, a legally-binding instrument is more likely to be applied worldwide than voluntary actions and considered the best option. In fact, it is to be hoped that a legal framework will ensure a strengthening directly in political commitments for actors around the world, leading then to stability, triggering concrete actions and certainty of a global market.

\section{Acknowledgments}

The authors would like to thank the Department of Chemical and Environmental Engineering at the University of Nottingham for allowing us to use their research facilities. The corresponding author would like to thank the CSIC (Spain) for the award of a JAE-Doc contract.

\section{References}

AMAP. Arctic Monitoring and Assessment Programme (1997-1998). A State of the Arctic Environment Report, 1997. Assessment Report: Arctic Pollution Issues, 1998.

AMAP. Arctic Monitoring and Assessment Programme (2002). Heavy Metals in the Arctic.

AMAP. Arctic Monitoring and Assessment Programme (2010). Updating Historical Global Inventories of Anthropogenic Mercury Emissions to Air. 
AMAP. Arctic Monitoring and Assessment Programme (2011). Arctic Pollution 2011. ISBN: 13978-82-7971-066-0, Oslo, pp38.

Basel Convention on the Control of Transboundary Movements of Hazardous Wastes and their Disposal (Basel, 22 March 1989), Annex 1.

Brussels, 11.3.2011, SEC(2011) 304 final, RECOMMENDATION FROM THE COMMISSION TO THE COUNCIL to amend Council Decision of 26 July 2010 on the participation of the European Union in negotiations of amendments to the 1998 Protocol on Heavy Metals to the 1979 Convention on Long-range Transboundary Air Pollution.

Canada (2008) Environment Canada: National Pollutant Release Inventory, Technical Report, 2008, Environment Canada, www.ec.gc.ca.

Canada (2010) Environment Canada and Health Canada. Report: Risk Management Strategy for Mercury; http://www.ec.gc.ca/doc/mercure-mercury/1241/indexe.htm \#goto240.

CCME (2006a) Canada-wide standards for mercury emissions from coal-fired power generation plants; http://www.ccme.ca.

CCME (2006b) Canada-wide Standards for mercury for the control of mercury emissions from the coal-fired electric power generation sector. Implementation plan for Saskatchewan; www.se.gov.sk.ca.

China Electricity Council (2006-2009) Annual Development Report for Chinese, Electricity Power Sector.

CHM (2004) Mercury Cycle. Chemistry of the Environment.CHM333 web page projects; http://www.princeton.edu/ chm333/2004/Mercury/index.html.

Clarkson TW, Magos L, Myers GJ (2003) The Toxicology of Mercury - Current Exposures and Clinical Manifestations. New Engl J Med 349:1731-1737. 
Convention on the Prevention of Marine Pollution by Dumping of Wastes and Other Matter (London, 13 November 1972a).

Convention for the Prevention of Marine Pollution by Dumping from Ships and Aircraft (Oslo, 15 Februray 1972b).

Convention for the Prevention of Marine Pollution from Land-Based Sources (Paris, 4 June 1974a).

Convention on the Protection of the Marine Environment of the Baltic Sea Area (Helsinki, 22 March 1974b).

Convention for the Protection of the Mediterranean Sea Against Pollution (Barcelona, 16 February 1976).

Convention for the Protection of the Marine Environment of the North-East Atlantic (Paris, 22 September 1992).

Council of the European Union (2011) Council conclusions. Review of the Community Strategy concerning Mercury, 3075th ENVIRONMENT Council meeting, Brussels, 14 March 2011; http://www.consilium.europa.eu/uedocs/cms_data/docs/pressdata /en/envir/119867.pdf

Davison RM, Reeve DA, Sloss LL, Smith IM (2003) Trace elements-occurrence, emissions and control. IEA Clean Coal Centre, pp 223-266.

Ebinghaus R, Banic C, Beauchamp S, Jaffe D, Kock HH, Pirrone N et al (2009) Spatial coverage and temporal trends of land-based atmospheric mercury measurements in the Northern and Southern Hemispheres. In: Pirrone N. \& Mason R. (ed) Mercury Fate and Transport in the Global Atmosphere. New York, USA: Springer. Chapter 9 pp $223-291$.

EC (2000) Directive 2000/76/EC of the European Parliament and of the Council of 4th December 2000 on the incineration of waste, Official Journal of the European 
Communities; http://eurlex.europa.eu/LexUriServ/LexUriServ.do?uri=OJ:L:2000: 332:0091:0111:EN:PDF

EC (2001a) Ambient Air Pollution by Mercury (Hg)- Position Paper; http://ec.europa.eu/environment/air/pdf/pp_mercury_toc.pdf

EC (2001b) Directive 2001/80/EC of the European Parliament and the Council of 23rd October 2001 on the limitation of emissions of certain pollutants into the air from large combustion plants, Official Journal of the European Communities; http://eurlex.europa.eu/LexUriServ/LexUriServ.do?uri=OJ:L:2001:309:0001:0001:EN:PDF

EC (2004) Directive 2004/107/EC of the European Parliament and of the Council of 15 December 2004 relating to arsenicm cadmium, mercury, nickel and polycyclic aromatic hydricarbons in ambient air, Official Journal of the European Union.

EC (2005) Communication from the Commission of the European Communities to the Council and the European Parliament- Community Strategy Concerning Mercury. \{SEC (2205) 101\}; http://eur-lex.europa.eu/LexUriServ/LexUriServ.do?uri=COM: 2005:0020:FIN:EN:PDF.

EC (2008a) Environment: Commission welcomes adoption of legislation to ban EU mercury exports. Source: European Commission. Published 25 September 2008; http://www.egovmonitor.com/node/21173.

EC (2008b) Directive 2008/1/EC of the European Parliaments and of the Council of 15 January 2008 concerning integrated pollution prevention and control, Official Journal of the European Union.

EC (2010) Directive 2010/75/EU of the European Parliament and of the Council of 24 November 2010 on industrial emissions (integrated pollution prevention and control) (recast); http://www.cogeneurope.eu/wp-content/uploads//2010/03/ Council-Common-Position-on-IPPC-IED_st11962.en09.pdf 
EPER (2000) Commission Decision of 17th July 2000 on the implementation of a EPER according to Article 15 of Council Directive 96/61/EC concerning integrated pollution prevention and control (IPPC)-(2000/479/EC). In: O. J. o. t. E. Communities (Ed.); http://eper.ec.europa.eu/eper/documents/comission_17072000 .pdf.

Fang F, Wang Q, Li J (2004) Urban Environmental Mercury in Changchun, a Metropolitan City in North-eastern China: Source, Cycle, and Fate. Sci Total Environ 330:159-170.

Feeley TJ, Murphy J, Hoffmann J, Granite E, Renninger S (2003) DOE/NETL's Mercury Control Technology Research Program for Coal-Fired Power Plants. EM 16-23, October 2003.

Feeley TJ, O'Palko BA, Jones AP (2008) Developing mercury control technology for coal-fired power plants - from concept to commercial reality. Main Group Chemistry 7(3):169-179.

Feeley TJ, Jones AP, Brickett LA, O'Palko BA, Miller CE, Murphy J (2009) An update on DOE's Phase II and Phase III mercury control technology R\&D program. Fuel Process Technol 90(11):1388-1391.

Feng X, Tang S, Shang L, Yan H, Sommar J, Lindqvist O (2003) Total gaseous mercury in the atmosphere of Guiyang, PR China. Sci Total Environ 304:61-72.

Gibb W, Quick W, Salisbury M (2003) Technology Status Review - Monitoring And Control Of Trace Elements, COAL R249 DTI/Pub URN 03/1582.

Glodek A, Pacyna JM (2009) Mercury emission from coal-fired power plants in Poland. Atmos Environ 43:5668-5673.

GLWQA (Ottawa, 15 April 1972).

GLWQA of 1978 (Ottawa, 22 November 1978). 
Granite E, Pennline H, Hoffman H (1999) Effects of Photochemical Formation of Mercuric Oxide. Ind Eng Chem Res 38:5034-5037.

Granite E, Pennline H, Hargis R (2000) Novel Sorbents for Mercury Removal from Flue Gas. Ind Eng Chem Res 39:1020-1029.

Granite E, Pennline H (2002) Photochemical Removal of Mercury from Flue Gas. Ind Eng Chem Res 41:5470-5476.

Granite E, Freeman MC, O'Dowd WJ, Hargis RA, Pennline H (2007) The Thief Process for Removal of Mercury from Flue Gas. J Enviro Manage 84(4):628-634.

GreenFacts (2004). Scientific Facts on Mercury [Online]; http://www.greenfacts.org/en/mercury/l-3/mercury-2.htm\#3p0 (Accessed 2010).

HELCOM (Helsinki Commission) (1988). Declaration on the Protection of the Marine Environment of the Baltic Sea Area (Helsinki, 15 February 1988); All past and present HELCOM Recommendations are available on the HELCOM website: http://www.helcom.fi.

Holmes CD, Jacob DJ, .Mason RP, Jaffe DA (2009). Sources and deposition of reactive gaseous mercury in the marine atmosphere. Atmos Environ 43:2278-2285.

IEP (India Environment Portal) (2011). OBSERVATION: Mercury rising, 2011, pp 1-4; http://www.indiaenvironmentportal.org.in

Jiang G-B, Shi J-B, Feng X-B (2006) Mercury pollution in China: An overview of the past and current sources of the toxic metal. Environ Sci Technol 15:3672-3678.

Kummer K (1995) International Management of Hazardous Wastes: The Basel Convention and Related Legal Rues (Clarendon Press, 1995).

Lindberg S, Bullock R, Ebinghaus R, Engstrom D, Feng XB, Fitzgerald W et al (2007) A synthesis of progress and uncertainties in attributing the sources of mercury in deposition. Ambio 36:19-32. 
Linqing J (1999) Rational and Clean Coal Use in China. Sinosphere 2(1):21-25.

Liu S, Nadim F, Perkins C, Carley RJ, Hoag GE, Lin Y et al (2002) Atmospheric Mercury Monitoring Survey in Beijing, China. Chemosphere 48:97-107.

Manivannan A, Ramakrishnan L, Seehra MS, Granite E, Butler JE, Tryk DA et al (2005) Mercury Detection at Boron Doped Diamond Electrodes Using a Rotating Disk Technique. J Electroanal Chem 577:287-293.

Maroto-Valer MM, Zhang Y, Granite EJ, Tang Z, Pennline HW (2005) Effect of Porous Structure and Surface Functionality on the Mercury Capture of a Fly Ash Carbon and its Activated Sample. Fuel 84:105-108.

MARPOL (1973/1978). Protocol of 1978 relating to the International Convention for the Prevention of Pollution from Ships of 2 November 1973; http://www.austlii.edu.au/au/other/dfat/treaties/1988/29.html

Masekoameng KE, Leaner J, Dabrowski J (2010) Trends in anthropogenic mercury emissions estimated for South Africa during 2000-2006. Atmos Environ 44:30073014.

Meij R, Winkel BH (2009) Trace elements in world steam coal and their behaviour in Dutch coal-fired power stations: A review. Int J Coal Geol 77:289-293.

Mercury Policy (2009) Project- Promoting policies to eliminate mercury use and reduce mercury exposure. International, Zero $\mathrm{Hg}$ Global Campaign, 2009, http://mercurypolicy.org/.

Milford JB, Pienciak A (2009) After the Clean Air Mercury Rule: Prospects for reducing mercury emissions from coal-fired power plants. Environ Sci Technol 43(8):2669-2673.

Mukherjee AB, Zevenhoven R (2006) Mercury in coal ash and its fate in the Indian subcontinent: A synoptic review. Sci Total Environ 368:384-392. 
Mukherjee AB (2008). Mercury emissions from industrial sources in India. Personal communication. 2008; http://www.htap.org/meetings/2008/2008_04/Presentations/ 07-04-08/4\%20-\%20Mukharjee.pdf

Mukherjee AB, Bhattacharya P, Sarkar A, Zevenhoven R (2009) Mercury emissions from industrial sources in India and its effects in the environment. New York: Springer; chap. 4. pp 81-112.

NACAA (National Association of Clean Air Agencies) (2007). State Mercury Programs for Utilities; http://www.4cleanair.org/Documents/StateTable.pdf

NAP (2010) Norwegian Action Plan for reducing mercury releases - 2010 http://www.klif.no/publikasjoner/2731/ta2731.pdf

NARAP (2000) North American Regional Action Plan on Mercury; Phase II- March 2000, http://www.cec.org/Page.asp?PageID=924\&ContentID=1297

NEG/ECP (1998) New England Governors/Eastern Canadian Premiers. Mercury Action Plan 1998, http://www.epa.gov/ne/eco/mercury/pdfs/Mercury_Action_Plan.pdf

Nelson PF (2007) Atmospheric emissions of mercury from Australian point sources, Atmos Environ 41:1717-1724.

Nguyen DL, Kim JY, Shim S-G, Zhang X-S (2011) Ground and shipboard measurements of atmospheric gaseous elemental mercury over the Yellow Sea region during 2007-2008. Atmos Environ 45:253-260.

OCAA (Ontario Clean Air Alliance) (2004). Mercury rising: Mercury emissions from Ontario Power Generation's Coal-Fired Plants. An OCAA Air quality report; www.cleanairalliance.org.

OECD (1973) Recommendation of the Council on Measures to Reduce All Man-made Emissions of Mercury to the Environment, C(73)172/final, 18 September 1973. 
OSPAR (Oslo-Paris Commision) (2009) Mercury losses from the chlor-alkali industry in 2007 including assessment of 2006 and 2007 data; http://www.ospar.org/documents\%5Cdbase\%5Cpublications\%5Cp00403_Mercury \%20losses\%20report\%202007.pdf

Pacyna EG, Pacyna JM, Fudala J, Strzelecka-Jastrzab E, Hlawiczka S, Panasiuk D (2006a) Mercury emissions to the atmosphere from anthropogenic sources in Europe in 2000 and their scenarios until 2020. Sci Total Environ370:147-156.

Pacyna EG, Pacyna JM, Steenhuisen F, Wilson S (2006b) Global anthropogenic mercury emission inventory for 2000. Atmos Environ 40:4048-4063.

Pacyna EG, Pacyna JM, Sundseth K, Munthe J, Kindbom K, Wilson S et al (2010) Global emission of mercury to the atmosphere from anthropogenic sources in 2005 and projections to 2020. Atmos Environ 44:2487-2499.

Pacyna JM, Pacyna EG, Steenhuisen F, Wilson S (2008) Global anthropogenic emissions of mercury to the atmosphere; http://www.eoearth.org/article/Global anthropogenic emissions of mercury to the atmosphere.

Pacyna JM, Pacyna EG, Aas W (2009) Changes of emissions and atmospheric deposition of mercury, lead, and cadmium. Atmos Environ 43:117-127.

Pacyna JM, Sundseth K, Pacyna EG, Jozewicz W, Munthe J, Belhaj M. et al (2010) An Assessment of Costs and Benefits Associated with Mercury Emission Reductions from Major Anthropogenic Sources. J. Air Waste Manage 60:302-315.

PARCOM (1990) Decision 90/3 on Reducing Atmospheric Emissions from Existing Chlor-Alkali Plants.

Pavlish JH, Hamre LL, Zhuang Y (2010) Mercury control technologies for coal combustion and gasification systems. Fuel 89:838-847. 
Pirrone N, Ferrara R, Hedgecock IM, Kallos G, Mamane Y, Munthe J et al (2003) Dynamic processes of mercury over the Mediterranean region: results from the Mediterranean Atmospheric Mercury Cycle System (MAMCS) project. Atmos Environ 37:21-39.

Pirrone N, Cinnirella S, Feng X, Finkelman RB, Friedli HR, Leaner J et al (2010) Global mercury emissions to the atmosphere from anthropogenic and natural sources. Atmos Chem Phys 10:5951-5964.

PP (Pollution Probe) (2003) Mercury in the environment: A premier. ISBN 0-91976451-7, June 2003; pp 85; www.pollutionprobe.org.

Presto AA, Granite EJ (2008) Noble Metal Catalysts for Mercury Oxidation in Utility Flue Gas. Platinum Metals Review, 52(3):144-154.

Protocol for the Prevention of the Pollution of the Mediterranean Sea by Dumping from Ships and Aircraft (Barcelona, 16 February 1976).

Protocol on the Protection of the Mediterranean Sea Against Pollution from Land-Based Sources (Athens, 17 May 1980).

Protocol on Heavy Metals to the Convention on Long-Range Transboundary Air Pollution (Aarhus, 24 June 1998).

Qi X, Lin Y, Chen J, Ye Y (2000) An Evaluation of Mercury emissions from the ChlorAlkali Indutria in China. J Environ Sci 12 (Suppl.):24-30.

Selin NE, Selin H (2006) Global Politics of Mercury Pollution: The Need for MultiScale Governance. Reciel 15(3):258-269.

Sloss LL (2006) The Status, Trends and Developments in Mercury Emission Legislation and Control in Europe. Personal communication. Mercury Control Technology Conference, December 11-13, 2006. 
Sloss LL (2008) Economics of Mercury Control, IEA Coal Researc-The Clean Coal Centre, CCC/134, London, UK, pp 51.

Sloss LL (2009) Impact of emissions legislation on coal-fired power plants. IEA Coal Researc-The Clean Coal Centre, CCC/145, London, UK.

Sundseth K, Pacyna JM, Pacyna EG, Munthe J, Belhaj M, Astrom S (2010) Economic Benefits from Decreased Mercury Emissions: Projections for 2020. J. Cleaner Production 18:386-394.

Tian HZ, Wang Y, Xue ZG, Cheng K, Qu YP, Chai FH et al (2010) Trend and characteristics of atmospheric emissions of $\mathrm{Hg}$, As, and Se from coal combustion in China, 1980-2007. Atmos Chem Phys 10:11905-11919.

UNECE (2000) Review of Strategies and Policies for Air Pollution AbatementExecutive Summary; http://www.unece.org/env/lrtap/conv/conclusi.htm.

UNEP (2002) Global Mercury Assessment, Chemicals Branch, Geneva, Switzerland, December 2002.

UNEP (2008a) Mercury Programme. Global Atmospheric Mercury Assessment: Sources, Emissions and Transport, December 2008; http://www.chem.unep.ch/mercury/ publications/default.htm.

UNEP (2008b) The Global Atmospheric Mercury Assessment, Technical Report: Arctic Monitoring and Assessment Programme, Chemicals Branch.

UNEP (2008c) Global Mercury Partnership; http://new.unep.org/hazardoussubstances/ LinkClick.aspx?fileticket $=\mathrm{nDg}$ VnoYrXa0\%3D\&tabid=3530\&language=en-US UNEP (2008-2009) Mercury Programme; http://www.unep.org/hazardoussubstances/ Portals/9/Mercury/Documents/para29submissions/India-Response\%20to\%20 questionnaire-COAL.pdf 
UNEP (2009) Developments. Zero Hg Global Campaign; http://www.zeromercury.org/ UNEP_developments/index.html.

UNEP (2009-2010) Global Mercury Partnership; http://www.unep.org/ hazardoussubstances/Mercury/GlobalMercuryPartnership/tabid/1253/Default.aspx UNEP (2010a) Project: Reducing Mercury Emissions from Coal Combustion in the Energy Sector; http://www.unep.org/hazardoussubstances/Mercury/Prioritiesfor Action/Coalcombustion/activities/tabid/4491/language/enUS/Default.aspx

UNEP (2010b) Process Optimization Guidance Document for Reducing Mercury Emissions from Coal Combustion in Power Plants, Chemical Branch, DTIE, Geneva, Switzerland, Draft report, July 2010.

UNEP (2011) Global Mercury Programme. Reduction of mercury emissions and use from the chlor-alkali sector partnership. January 2011; http://www.eurochlor.org/upload/ documents/document583.pdf

UNEP/GC (2004) Views Submitted by Governments, Intergovernmental Organizations and Non-Governmental Organizations on the Progress Made on a Mercury Programme (UNEP/GC.23/INF/19, 23 December 2004)

USEPA (1997a) Mercury study report to congress, EPA-452/R-97-010 VIII, United States Environmental Protection Agency, Washington, DC, USA.

USEPA (1997b) Mercury Study Report to Congress; EPA-452/R-97-003; US EPA

Office of Air Quality Planning and Standards. US Government Printing Office: Washington, DC; December 1997.

USEPA (1998) A study of Hazardous Air Pollutant Emissions from electric utility steam generating units: final report to congress; EPA-453/R-98-004a; US EPA Office of Air Planning and Standards. US Government Printing Office; Washington, DC. 
USEPA (2000) Regulatory Finding on the Emissions of Hazardous Air Pollutants from Electric Utility Steam Generating Units. Fed. Regis. 65:79825-79831.

USEPA (2002a) Control of mercury emissions from coal-fired electric utility boilers, Technical report. EPA-600/R-01-109. United States Environmental Protection Agency, Washington, DC, USA.

USEPA (2002b) ICR data, Technical report, United States Environmental Protection Agency; http://www.epa.gov/ttn/atw/combust/utiltox/icrdata.xls.

USEPA (2004a) Proposed National Emission Standards for Hazardous Air Pollutants; and in the Alternative, Proposed Standards of Performance for New and Existing Stationary Sources: Electric Utility Steam Generating Units. Fed. Regis. 69:46524752.

USEPA (2004b) Supplemental Notice for the Proposed National Emission Standards for Hazardous Air Pollutants; and in the Alternative, Proposed Standards of Performance for New and Existing Stationary Sources: Electric Utility Steam Generating Units. Fed. Regis. 69:12398-12472.

USEPA (2005a) National Emission Inventory (NEI). Technical Report, US EPA, www.epa.gov.

USEPA (2005b) Revision of December 2000 Regulatory Finding on the Emissions of Hazardous Air Pollutants from Electric Utility Steam Generating Units and the Removal of Coal-and Oil-Fired Electric Utility Steam Generating Units from the Section 112(c) List. Fed. Regis. 70:15994-16035.

USEPA (2005c) Standards of Performance for New and existing Stationary Sources: Electric Utility Steam Generating Units, Final Rule. Fed. Regis. 70:28606-28700. USEPA (2005d) Rule to Reduce Interstate Transport of Fine Particulate Matter and Ozone (Clean Air Interstate Rule). Fed. Regis. 70:25162-25405. 
USEPA (2006) EPA`s Roadmap for mercury. I. Addressing Mercury Releases. July 2006. EPA-HQ-OPPT-2005-0013. http://www.epa.gov/mercury/roadmap.htm.

USEPA (2008a). State of New Jersey v. EPA, No. 05-1097 (D. C. Cir. Feb 8, 2008).

USEPA (2008b) N.C. v. EPA, 531 F.3d 896 (D.C. Cir. 2008), modified on rehearing, _F.3d_, Docket No. 05-1244 (D.C. Cir. Dec. 23, 2008).

USEPA (2009) Clean Air Mercury Rule: http://www.epa.gov/camr/; March 2009.

USEPA (2011) National Emission Standards for Hazardous Air Pollutants from Coaland Oil-fired Electric Utility Steam Generating Units and Standards of Performance for Fossil-Fuel-Fired Electric Utility, Industrial-Commercial-Institutional, and Small Industrial-Commercial-Institutional Steam Generating Units; http://www.epa.gov/airquality/powerplanttoxics/pdfs/proposal.pdf

Wang S, Zhang L, Li GH, Wu Y, Hao JM, Pirrone N et al (2010a) Mercury emission and speciation of coal-fired power plants in China. Atmos Chem Phys 10:11831192.

Wang S, Zhang L, Wu Y, Ancora MP, Zhao Y, Hao J (2010b) Synergistic mercury removoal by convencional pollutant control strategies for coal-fired power plants in China. J Air Waste Manag Assoc 60(6):722-730.

Wang S (2011) Mercury emissions from coal-fired power plants in China. Personal communication. UNEP INC2 Technical Meeting, Chiba, Japan, January 23, 2011.

Wiederkehr P (1993) Control of hazardous air pollutants in OECD countries: a comparative policy analysis. In Managing Hazardous air pollutants: state of the art; Proceedings of the first international conference on managing hazardous air pollutants, Washington, DC, 4-6 Nov 1991. Chow, W., Connor, K. K., Eds.; Lewis Publishers EPRI TR- 101890: Boca Raton, FL, US, pp 29-43. 
WHO (1990) Environmental health criteria 101: Methylmercury. World Health Organization, International Programme on Chemical Safety, Geneva; http://www.inchem.org/documents/ehc/ehc/ehc101.htm

WHO (2003) Elemental mercury and inorganic mercury compounds : human health aspects. World Health Organization, Concise international chemical assessment document 50, Geneva.

Wu Y, Wang S, Streets DG, Hao J, Chan M, Jiang J (2006) Trends in Anthropogenic Mercury Emissions in China from 1995 to 2003. Environ Sci Technol 40:53125318.

Wu Y, Streets DG, Wang SX, Hao JM (2010) Uncertainties in estimating mercury emissions from coal-fired power plants in China. Atmos Chem Phys 10:2937-2947. 


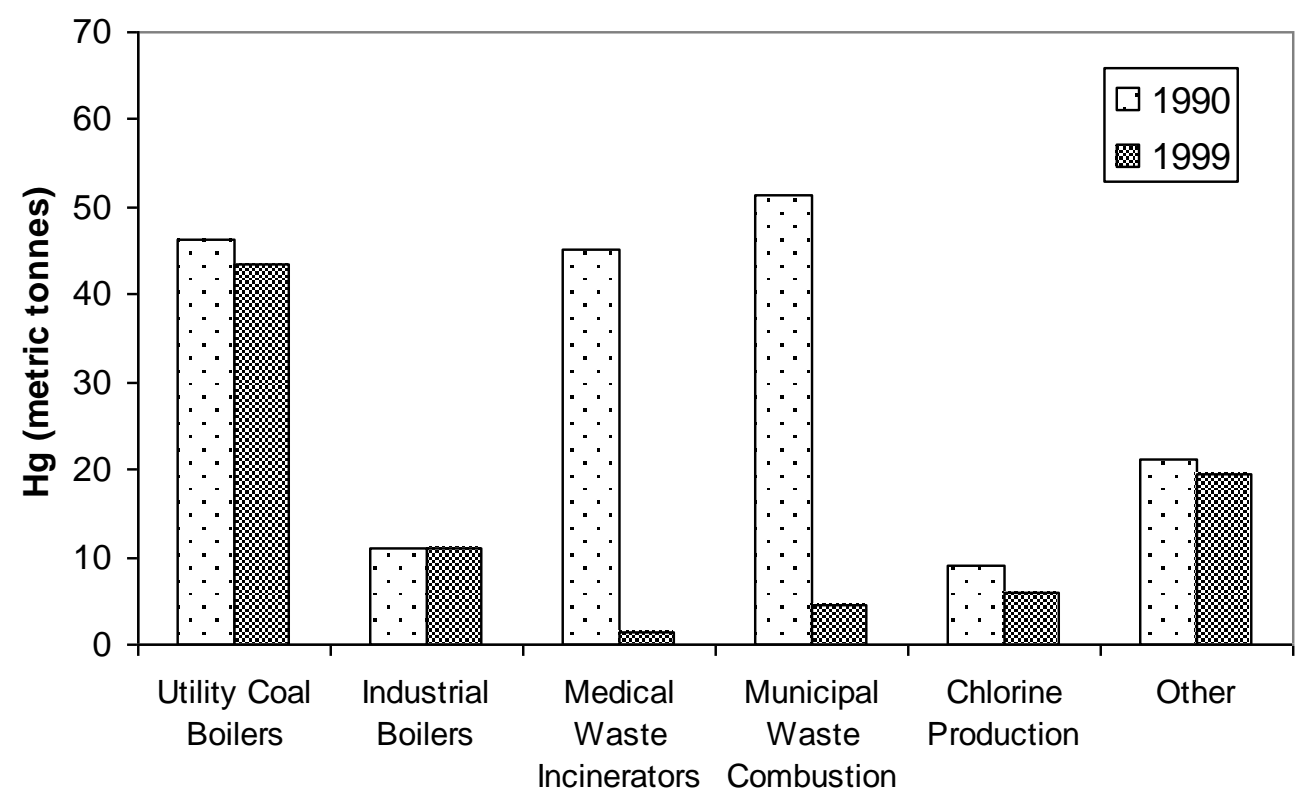

Figure 1

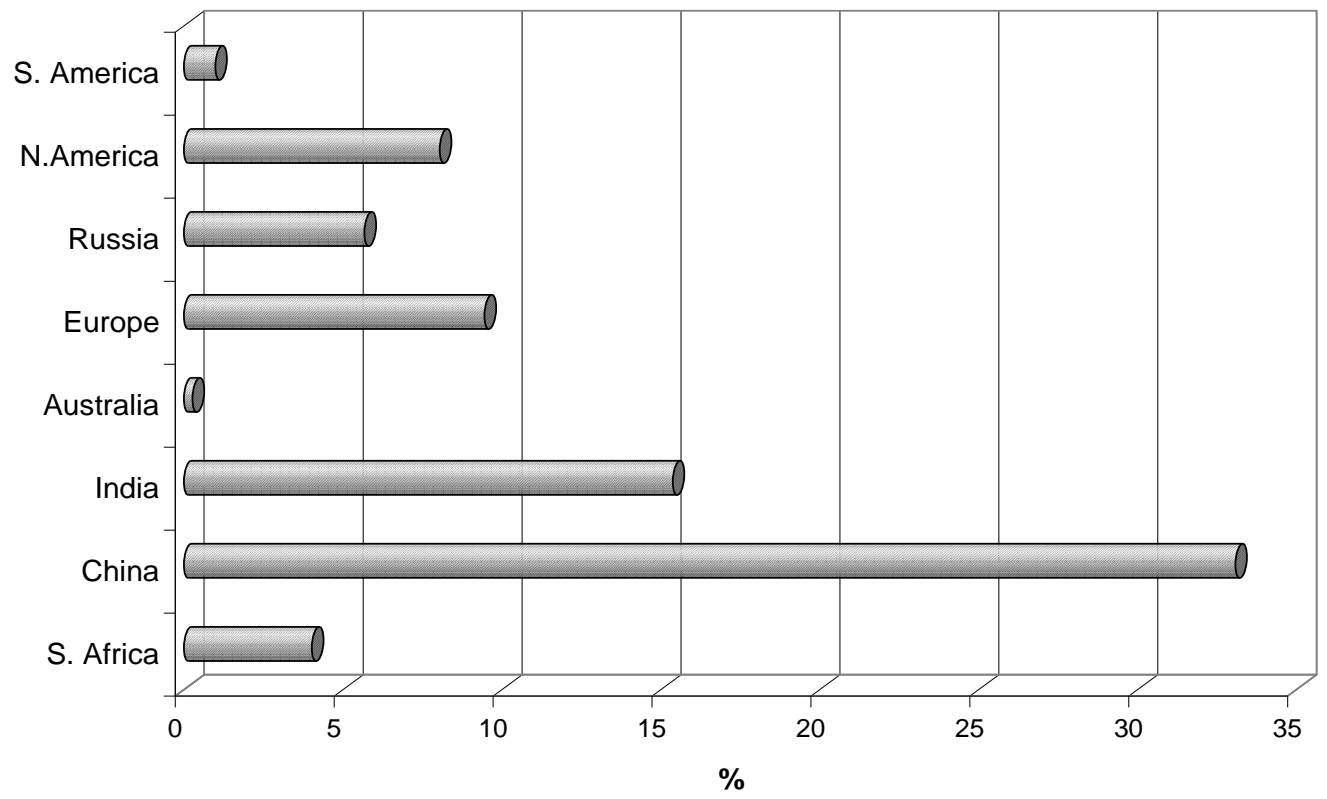

Figure 2 